Jurnal Ilmu dan Teknologi Kelautan Tropis, Vol. 8, No. 1, Hlm. 227-235, Juni 2016

\title{
EVALUATION OF MICROBIAL FLOC AND MICROALGAE Spirulina platensis COMBINATION FOR JUVENILE COBIA Rachycentron canadum DIETS ON GROWTH AND PHYSIOLOGICAL RESPONSES AFTER IMMERSION IN FRESHWATER
}

\author{
KOMBINASI MIKROBIAL FLOK DAN MIKROALGA Spirulina platensis UNTUK \\ PAKAN JUVENIL COBIA Rachycentron canadum TERHADAP PERTUMBUHAN DAN \\ RESPON FISIOLOGIS SETELAH PERENDAMAN AIR TAWAR
}

\author{
Suryadi Saputra $^{1 *}$, Muhammad Agus Suprayudi ${ }^{2}$, Enang Harris ${ }^{2}$, \\ Mia Setiawati ${ }^{2}$, Widanarni ${ }^{2}$, and Suciantoro ${ }^{1}$ \\ ${ }^{1}$ Main Center for Marine Aquaculture, Minister of Marine and Fisheries Affairs, Lampung. \\ ${ }^{2}$ Aquaculture Department, Faculty of Fisheries and Marine Sciences, \\ Bogor Aqricultural University, Bogor \\ *E-mail: sy.saputra1973@gmail.com
}

\begin{abstract}
In marine aquaculture, immersing marine fish species in fresh water can remove ectoparasite that adhere to all over the fish body. This study aimed to evaluate the impacts of combining microbial floc and microalgae Spirulina platensis in juvenile cobia diet on growth performance and stress responses after immersion in aerated fresh water for 15 minutes. The fishes were reared in concrete tanks for 40 days before collecting data on their growth performance. The stress response was determined by measuring both glucose and cortisol levels before $(0 \mathrm{~h})$ and after $(1,2,4,6,24$ hours $)$ immersion. The fishes fed on the $15 \%$ of combining microbial flock and microalgae Spirulina platensis diet showed the highest growth rate with the lowest feed conversion ratio compared to other treatments. The cortisol level of juvenile cobia in both the $15 \%$ and $30 \%$ combination of microbial floc and microalgae Spirulina platensis treatments did not increase during the first hour following the immersion compared to the control treatment. The glucose level also increased after one hour immersion in freshwater of all treatments. This indicated that feeding juvenile cobia on microbial flocs and microalgae diets had a retarding effect on the physiological responses (cortisol and glucose) after immersion in fresh water.
\end{abstract}

Keywords: microbial, microalga, Spirulina, glucose, cortisol, stress, cobia

\section{ABSTRAK}

Penelitian ini bertujuan untuk mengevaluasi kombinasi mikrobial flok dan mikroalga Spirulina platensis dalam pakan juvenil cobia terhadap kinerja pertumbuhan dan respons stress setelah direndam air tawar selama 15 menit dengan aerasi. Ikan dipelihara dalam bak beton selama 40 hari kemudian diambil data kinerja pertumbuhannya. Setelah diaklimatisasi selama seminggu, ikan direndam dalam air tawar. Data respons fisiologis melalui pengukuran kadar glukosa dan kortisol. Sebelum diberi perlakuan (0 jam) dan setelah 1, 2, 4, 6, 24 jam. Ikan yang diberikan pakan kombinasi mikrobial flok dan mikroalga Spirulina platensis sebesar 15\% menunjukkan pertumbuhan yang lebih cepat dengan konversi pakan yang lebih rendah dibanding kontrol dan perlakuan lainnya. Hasil pengukuran terhadap kadar kortisol setelah 1 jam, diperoleh bahwa ikan yang diberikan pakan kombinasi mikrobial flok dan mikroalga Spirulina platensis 15\% dan 30\% tidak mengalami peningkatan kortisol yang berbeda dengan kontrol. Kadar glukosa mengalami kecenderungan meningkat mulai dari jam ke-1 dan tertinggi pada jam ke-2 kemudian kembali menurun pada jam ke-4 hingga terjadi keseimbangan fisiologis di jam ke-6 pada semua perlakuan. Dengan demikian ikan yang diberikan pakan kombinasi mikrobial flok dan mikroalga Spirulina platensis $15 \%$ dan 30\% dapat mengurangi dampak negatif (stress) setelah direndam dalam air tawar.

Kata kunci: mikrobial, mikroalga, Spirulina, glukosa, kortisol, stres, cobia 


\section{INTRODUCTION}

Cobia (Rachycentron canadum) is a promising candidate for marine aquaculture (Kaiser and Holt, 2005; Liao et al., 2004). It grows rapidly and has a good feed conversion rate and meat quality (Zhou et al., 2011). However, its availability in nature is limited (Kaiser and Holt, 2005). Juvenile cobia, like other marine fish species, are highly sensitive to fish farming activities involving high stress levels, such as high stocking density, temperature changes, salinity, dissolved oxygen and chemical treatment (Schwarz et al., 2007).

In marine aquaculture, immersing marine fish species in fresh water can remove ectoparasite that adhere all over the fish body within 10-30 minutes. However, the mentioned procedure affects the water-salt balance in the fish body, which is well-known as osmoregulation. A disruption in the fish osmoregulation process can result in dehydration due to osmotic pressure (Wedemeyer, 1996). Drastic changes in water salinity (e.g. by immersion in freshwater) results into osmotic changes that stress the fish (Fujaya, 2004). The ability of dealing with stressful condition (due to osmotic pressure) strongly depends on the capability of the fish to reorganize its energy investment in a relatively short period of time (Tseng and Hwang, 2008), so that the energy invested in growth can partially be used to recover from stress.

Microbial floc is a renewable raw material in feed formulation, which results from the conversion of inorganic nitrogen (mainly ammonia) by heterotrophic bacteria into microbial nutrients (biomass). It contains essential nutrients such as protein (19-58\%), lipid (2-39\%), carbohydrates $(27-59 \%)$, ash (2-17\%) and vitamins C (Crab et al., 2010 and 2009; Crab 2010). Research demonstrated that the microbial flock can improve growth performance in both shrimp and tilapia (De Schryver et al., 2008). It is also considered to be a natural food that has been used in shrimp and fish hatchery. In addition, the microalgae Spirulina platensis plays an important role in the development and growth of fish larvae. These microalgae also contain important nutrients such as protein (60-70\%), lipid (4-7\%), carbohydrate (13. $6 \%$ ), pro-vitamin $\mathrm{A}$, antioxidant (Carotene and phycocyanin) and $\beta$-carotene (Carrieri et al., 2010). Previous research has shown that Spirulina platensis microalgae used as feed supplement in fish or shrimp diets (SilvaNeto et al., 2012) can substitute fish meal up to $40 \%$ and $75 \%$ in tilapia and shrimp diets respectively (Olivera-Novoa et al., 1998, Macias-Sancho et al., 2014), without negatevely affecting growth performance and survival.

A combination of microbial floc and microalgae Spirulina platensis (MFMS) in a given formulated feed is expected to improve fish growth performance and health status. Kuhn et al. (2009) reported that the microbial floc can be considered as probiotics that can increase the shrimp growth performance. Nakono et al. (2003) recorded that the lack of cellulose from the cellular structure of Spirulina render it easily digestible, thus, increase fish appetite, improve feed intake and nutrient digestibility and in turn enhance the health of fish, increasing the ability to fight off infections through the reduction of stress levels

Little is known, however, about the use of microbial floc and microalgae Spirulina platensis to reduce or substitute fish meal and soybean meal in marine fish diets. Thus, this study aims to evaluate the impacts of combining microbial floc and microalgae Spirulina platensis in juvenile cobia diets on growth performance and stress responses immersion in fresh water.

\section{METHODS}

The current study was conducted in the wet laboratory of Main Center for Marine Aquaculture in Lampung from December 2014 to January 2015. Proximate analyses 
were performed in both fish health and nutrition laboratories in the Faculty of Fisheries and Marine Sciences, Bogor Agricultural University. Meanwhile, the cortisol and glucose levels were analyzed in the iso-tope/ radioactive laboratory of Bogor Animal Research Center.

\subsection{Formulated Feed Composition}

The feed used in this study was in the form of dried pellets. The tested feed was formulated to contain equal energy-protein ratio in all of the treatments. It only differed with regard to its microbial floc and microalgae Spirulina platensis contents. Microbial floc and Spirulina platensis microalgae were combined at a ratio of 75:25 on weight bases. Four treatments (with 3 replicates) were applied in this study, consisting of diets with different contents of the microbial floc and microalgae Spirulina platensis combination i.e., $15 \%, 30 \%, 45 \%$, and $0 \%$ (a conventional diet of fish without microbial floc and microalgae Spirulina platensis as a control).
The combination of MFMS diet was made to substitute soybean meal since the nutrient composition of MFMS and soybean meal is almost similar while soybean meal price is more expensive than that MFMS. Feed formulation is presented in Table 1 .

\subsection{Experimental Fish}

Hundred and eighty juvenile cobia at an average body weight of $41.4 \pm 0.06 \mathrm{~g}$ were used in the current study. The fishes originated from the hatchery of the Main Center for Marine Aquacultur, Lampung Indonesia. The fishes were reared in small nets $(100 \times 100 \times 150 \mathrm{~cm})$ within concrete tanks (size $200 \times 200 \times 200 \mathrm{~cm}^{3}$ ) at a density of $15 \mathrm{fish} /$ net for a period of 40 days. All of the nets were equipped with aeration and water circulation (open system) systems and water was daily exchanged $(100 \%)$. The fishes were acclimatized to laboratory conditions for 7 days prior to the study. After the acclimatization period, the fish were starved for 24 hours in order to empty

Table 1. Proximate analysis of experimental diets (MFMS $(\%)=$ the proportion of the microbial floc and Spirulina platensis combination in the diet).

\begin{tabular}{lcccc}
\hline \multirow{2}{*}{ Ingredients } & \multicolumn{4}{c}{ MFMS (\%) } \\
\cline { 2 - 5 } & 0 & 15 & 30 & 45 \\
\hline Fish meal & 18.4 & 18.1 & 16.2 & 15.9 \\
Mixed microbial floc and S.platensis meal & 0.0 & 14.8 & 28.8 & 44.8 \\
Soybean meal & 53.6 & 35.3 & 21.0 & 1.1 \\
Meat and bone meal & 13.5 & 13.5 & 13.5 & 13.5 \\
Wheat meal & 2.0 & 2.0 & 2.0 & 2.0 \\
Tapioca meal & 3.0 & 3.0 & 3.0 & 3.0 \\
Squid oil & 2.5 & 6.3 & 8.5 & 12.7 \\
Vitamins premix & 3.0 & 3.0 & 3.0 & 3.0 \\
Attractant & 2.0 & 2.0 & 2.0 & 2.0 \\
Puremethyl cellulose & 2.0 & 2.0 & 2.0 & 2.0 \\
\hline Proximate composition & & & & \\
\hline Crude Protein & 36.95 & 38.65 & 38.18 & 38.15 \\
Crude fat & 6.26 & 10.82 & 12.38 & 17.03 \\
Ash & 13.70 & 15.10 & 15.52 & 18.34 \\
Crude fiber & 2.57 & 1.25 & 2.13 & 1.22 \\
Nitrogen free extract & 40.52 & 34.18 & 31.79 & 25.25 \\
\hline Energy (kcal/kg dry matter) & 430.02 & 454.99 & 456.79 & 472.15 \\
C/P & 11.64 & 11.77 & 11.96 & 12.38 \\
\hline
\end{tabular}


the fish digestive tract. The feeding was done twice daily at sa-tiation (08.00 a.m. and 2.00 p.m.). The nets and the tanks were siphoned twice daily, an hour after feeding, to maintain a good water quality.

To evaluate of stress responses of fish, thirty juvenile cobia that had been kept for 40 days by feeding of the microbial floc and microalgae Spirulina platensis combination fed within each concrete tank (size $200 \mathrm{x}$ $200 \times 200 \mathrm{~cm}^{3}$ ). Four concrete tanks were used as experimental units. Constant aeration was provided by an air blower. Fish were acclimatized for a week. All fish in concrete tanks were immersed in freshwater for fifteen minutes with aeration. Fish were returned to the concrete tanks after the immersion.

\subsection{Data Collection}

Data on fish growth (body length and body weight) was measured once a week. The feed consumption of each treatment was recorded and readjusted according to the obtained biomass at every treatment weekly. Meanwhile, data on stress responses (cortisol and glucose) were taken from juvenile cobia blood samples (approximately $1 \mathrm{~mL}$ ), using a $23 \mathrm{G}$ needle ( $1 \mathrm{~mL}$ shyrink), on the tail vein and immediately placed into a cool-box to prevent blood clotting. Blood samples were taken from three juvenile cobia as followed: before immersion, 1 hour, 2 hours, 4 hours, 6 hours and 24 hours after immersion. The immersion period took a minute for each fish. Blood samples were centrifuged for 5 minutes at a temperature of $4^{\circ} \mathrm{C}$ to separate the blood cells and the serum. Serum inserted into the micro tube using a micropipette (0.1$100 \mathrm{~mL}$ ) and temporarily stored in a freezer prior to analysis.

\subsection{Growth Parameters}

The average body weight gain ( $\mathrm{AB}$ $\mathrm{GW})$ as (g/fish) was estimated according to the following equation:

Final weight gain $(\mathrm{g} / \mathrm{fish})=$ Mean of weight (g) at the end of the experimental period- weight $(\mathrm{g})$ at the beginning of the experimental period

Weight gain $(\mathrm{WG} \%)=$ Gain/initial weight $\mathrm{x}$ $100 \%$

Feed conversion ratio $(\mathrm{FCR})=$ Total feed fed $(\mathrm{g} /$ fish)/total wet weight gain (g/fish) .....

Specific growth rate $(\mathrm{SGR})=\left(\mathrm{In} \mathrm{W}_{1}\right.$-In $\left.\mathrm{W}_{0}\right) /$

T) $\mathrm{x} 100$

Where, $\mathrm{W}_{1=}$ final weight, $\mathrm{W}_{0}=$ initial weight, $\mathrm{T}=$ time between $\mathrm{W}_{1}$ and $\mathrm{W}_{0}$

\subsection{Chemical Analysis}

Feed samples were analysed for dry matter following the AOAC (1995) method. Water content analysis with Gravimetric method. Crude protein (Kjeldhal), lipid (Soxhlet) ash (Gravimetric) and crude fiber (Vansus). Meanwhile, glucose and cortisol levels were analysed following the Radioimmunoassay (RIA) method.

\subsection{Statistical Analysis}

All data were analyzed using ANOVA test that was followed by a Tukey HSD test if significant differences were found. All statistical analyses were examined at $\mathrm{P}<$ 0.05 .

\section{RESULTS AND DISCUSSION}

\subsection{Results}

All fish readily accepted the experimental diets and no significant differences among treatments with the fish survival rate (Table 2). Juvenile cobia in the $15 \%$ of microbial floc and microalgae Spirulina platensis treatment showed the weight gain (WG) and specific growth rate (SGR) were significantly increased $(P<0.05)$ and the lowest feed conversion ratio (FCR) compared to control $(0 \%)$ (Table 2). Meanwhile, juvenile cobia in the $45 \%$ of microbial floc and microalgae Spirulina platensis treatment showed WG and SGR were significantly reduced and 
FCR were significantly increased $(P<0.05)$ compared to control (0\%) (Table 2).

Result of measurement of blood serum analyses of juvenile cobia given an experimental diet after immersion in fresh water showed different stress response. This indicates that feeding of microbial floc and microalgae Spirulina platensis combination fed give a different effect on stress responses of juvenile cobia (Figure 1 and 2 ; Table 3 ). The cortisol decreased during 1 hour after immersion in the $15 \%$ and $30 \%$ of microbial floc and microalgae Spirulina platensis treatments. Otherwise, in the control $(0 \%)$, the cortisol level increased $1 \mathrm{~h}$ and all treatment of the cortisol levels returned to the basal level $2 \mathrm{~h}$ (Figure 1). In the $45 \%$ of microbial floc and microalgae Spirulina platensis treatment, the cortisol level increase during $1 \mathrm{~h}$, then decreased to under basal level $2 \mathrm{~h}$ and increased again during $4 \mathrm{~h}$. finally, fish recovered within $6 \mathrm{~h}$ after immersion. (Figure 1).

Table 2. Growth performance of juvenile cobia fed with microbial floc and microalgae Spirulina platensis during a 40 days rearing period.

\begin{tabular}{lcccc}
\hline \multirow{2}{*}{ Parameter } & \multicolumn{4}{c}{ Microbial floc and microalgae Spirulina platensis $(\%)$} \\
\cline { 2 - 5 } & 0 & 15 & 30 & 45 \\
\hline Initial weight $(\mathrm{g})$ & $41.38 \pm 0.1$ & $41.37 \pm 0,07$ & $41.44 \pm 0.1$ & $41.43 \pm 0.04$ \\
Final weight $(\mathrm{g})$ & $111.66 \pm 6.9^{\mathrm{a}}$ & $125.43 \pm 1.7^{\mathrm{b}}$ & $104.43 \pm 5.6^{\mathrm{a}}$ & $87.00 \pm 3.1^{\mathrm{c}}$ \\
Weight gain $(\%)$ & $169.83 \pm 16.2^{\mathrm{a}}$ & $203.21 \pm 4.4^{\mathrm{b}}$ & $151.90 \pm 13.1^{\mathrm{a}}$ & $109.99 \pm 7.3^{\mathrm{c}}$ \\
Survival rate $(\%)$ & 100 & 100 & 100 & 100 \\
Specific growth rate & $2.51 \pm 0.2^{\mathrm{a}}$ & $2.81 \pm 0.04^{\mathrm{b}}$ & $2.33 \pm 0.1^{\mathrm{a}}$ & $1.87 \pm 0.1^{\mathrm{c}}$ \\
$(\% /$ day) & $2.02 \pm 0.1^{\mathrm{a}}$ & $1.93 \pm 0.2^{\mathrm{a}}$ & $2.40 \pm 0.2^{\mathrm{b}}$ & $2.98 \pm 0.2^{\mathrm{c}}$ \\
Feed convertion ratio & & & &
\end{tabular}

Data expressed as mean \pm SD $(n=3)$; Value in the same line with different superscript letters are significantly different $(\mathrm{P}<0.05)$.

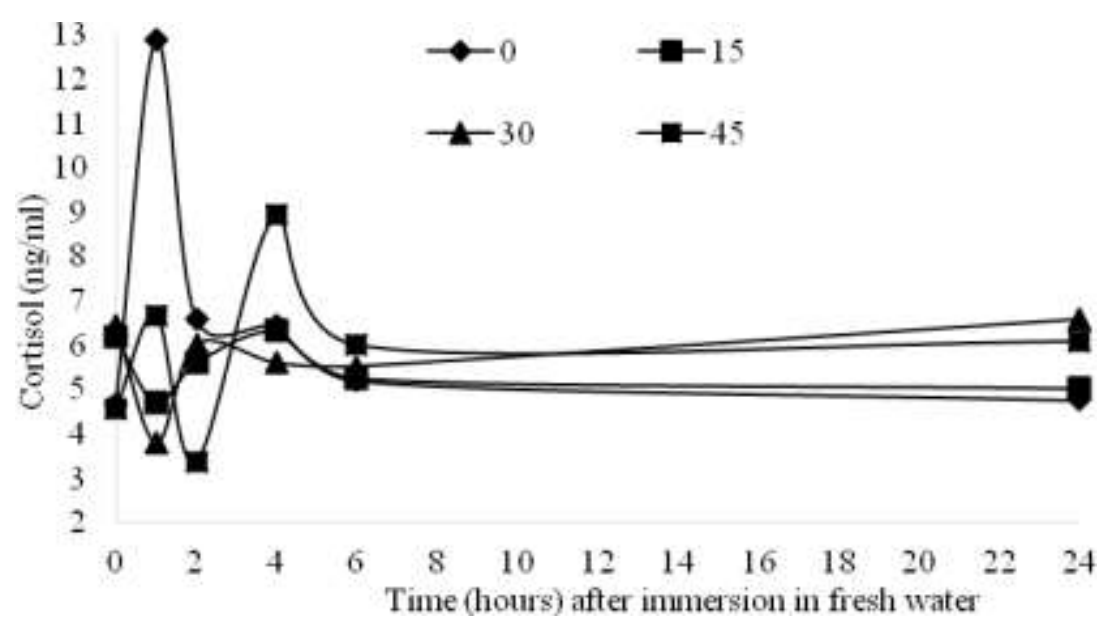

Figure 1. Time course of cortisol responses of juvenile cobia fed with microbial floc and microalgae Spirulina platensis following experimental immersion of the fish in fresh water [Data expressed as mean $\pm \operatorname{SD}(n=3)$ ]. 
Blood glucose levels analyses of juvenile cobia showed similar trend in all treatments (Figure 2 and Table 3). The highest level was observed in $2 \mathrm{~h}$ following the immersion and returned to basal level in $4 \mathrm{~h}$ after immersion. (Figure 2). The glucose level of Juvenile cobia in the $45 \%$ microbial floc and microalgae Spirulina platensis was observed to drastically decrease on the 4 hour following immersion and returned to basal level on $6 \mathrm{~h}$ after immersion. The highest glucose level ( 2 hours after immersion) was observed in the $15 \%$ of microbial floc and microalgae Spirulina platensis treatment, meanwhile the lowest level was observed in the $45 \%$ of microbial floc and microalgae Spirulina platensis treatment (Figure 2).

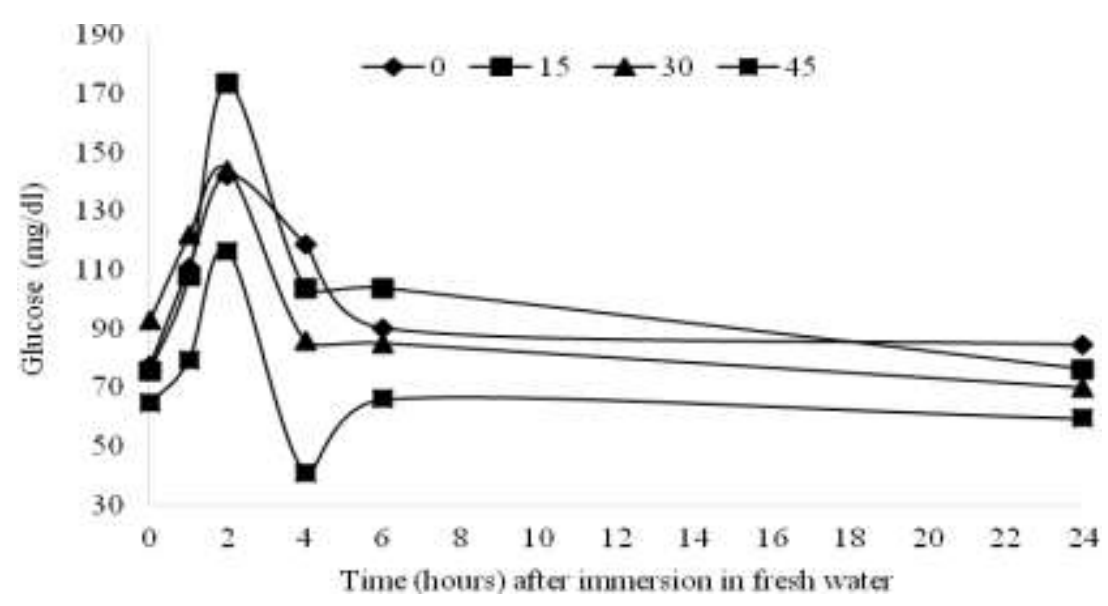

Figure 2. Time course of glucose responses of juvenile cobia fed with microbial floc and microalgae Spirulina platensis following experimental immersion of the fish in freshwater [Data expressed as mean $\pm \mathrm{SD}(\mathrm{n}=3)$ ].

Table 3. Haemotological responses of juvenile cobia fed with MFMS following experimental immersion of the fish in freshwater.

\begin{tabular}{cccccc}
\hline \multirow{2}{*}{ Parameters } & Time & \multicolumn{4}{c}{ microbial floc and microalgae Spirulina platensis $(\%)$} \\
\cline { 2 - 5 } & (Hours) & 0 & 15 & 30 & 45 \\
\hline & Pre & $4.69 \pm 0.4$ & $6.21 \pm 2.3$ & $6.44 \pm 0.3$ & $4.55 \pm 0.4$ \\
Cortisol & 1 & $12.87 \pm 4.2^{\mathrm{a}}$ & $4.72 \pm 1^{\mathrm{b}}$ & $3.81 \pm 0.7^{\mathrm{b}}$ & $6.67 \pm 1^{\mathrm{b}}$ \\
$(\mathrm{ng} / \mathrm{ml})$ & 2 & $6.60 \pm 0.7^{\mathrm{a}}$ & $5.61 \pm 1.4^{\mathrm{b}}$ & $6.03 \pm 1^{\mathrm{b}}$ & $3.38 \pm 0.1^{\mathrm{b}}$ \\
& 4 & $6.44 \pm 0.5$ & $6.33 \pm 1.4$ & $5.60 \pm 0.4$ & $8.93 \pm 3.8$ \\
& 6 & $5.21 \pm 0.8$ & $5.27 \pm 1.5$ & $5.52 \pm 3.1$ & $6.00 \pm 0.5$ \\
& 24 & $4.77 \pm 1.0$ & $5.04 \pm 1.6$ & $6.58 \pm 0.4$ & $6.08 \pm 1.5$ \\
& Pre & $77.32 \pm 32.8$ & $75.39 \pm 21.2$ & $92.91 \pm 15.9$ & $64.61 \pm 2.9$ \\
Glucose & 1 & $110.88 \pm 32.5$ & $108.058 \pm 20.2$ & $121.73 \pm 45.7$ & $79.47 \pm 2.5$ \\
$(\mathrm{mg} / \mathrm{dl})$ & 2 & $142.19 \pm 42.8$ & $173.38 \pm 32.2$ & $144.22 \pm 13.9$ & $116.53 \pm 34.1$ \\
& 4 & $118.57 \pm 21.7^{\mathrm{a}}$ & $103.88 \pm 8.9^{\mathrm{a}}$ & $85.8 \pm 13.5^{\mathrm{ab}}$ & $40.82 \pm 22.9^{\mathrm{b}}$ \\
& 6 & $90.09 \pm 18.8^{\mathrm{ab}}$ & $103.76 \pm 15.9^{\mathrm{a}}$ & $85.117 \pm 3.7^{\mathrm{ab}}$ & $65.91 \pm 6.1^{\mathrm{b}}$ \\
& 24 & $84.44 \pm 5.6^{\mathrm{a}}$ & $76.19 \pm 7.6^{\mathrm{a}}$ & $69.97 \pm 9.1^{\mathrm{a}}$ & $59.35 \pm 11.8^{\mathrm{b}}$ \\
\hline
\end{tabular}

Data expressed as mean \pm SD $(n=3)$; Value in the same line with different superscript letters are significantly different $(\mathrm{P}<0.05)$ 


\subsection{Discussion}

Alternative protein source, which is derived from microbial floc and microalgae Spirulina platensis, has been already used in aquaculture as feed supplement in substituting other protein sources. Crab et al. (2009) succeeded in using microbial floc as protein source in tilapia diet. Kuhn et al. (2009) demonstrated that microbial floc could subtitute both fishmeal and soybean meal in shrimp, which resulted in better growth performance. Teimouri et al. (2013) suplementing Spirulina platensis meal in rainbow trout feed. Macias-Sancho et al. (2014) substitute fish meals with microalgae Spirulina platensis until $75 \%$ without negative effect of growth and survival rate in shrimp.

The combination of microbial floc and microalgae Spirulina platensis ingredients at $15 \%$ in this study significantly increased the growth performance in juvenile cobia. No significant differences were observed at $30 \%$ of microbial floc and microalgae Spirulina platensis treatment compared with the control $(0 \%)$.

The $45 \%$ of microbial floc and microalgae Spirulina platensis treatment reduced the growth performance as compared to the controls, indicating that there was an imbalance in the feed amino acids profile, especially arginine and lysine, which are of capital importance in juvenile fish development. Arginine degradation can result in an increase in the use of lysine that can slow the fish growth. Lysine is of capital importance for fish growth. It has been shown that its deficiency can cause loss of appetite and slow growth in japanese sea bass (Mai et al., 2006).

The physiological responses of juvenile cobia after being immersed in fresh water for 15 minutes (with aeration) are presented in Figure 1.and 2 as well as in Table 3. The results showed fluctuations in both cortisol and glucose levels in the fish blood serum, indicating that the fish responded to changes in water salinity. According to Fujaya (2004), drastic changes in water salinity due to immersion can result in changes in the fish osmoregulation system, which may stress the fish. Tseng and Hwang (2008) reported that the success of fish in overcoming stress due to osmotic pressure strongly depends on the fish's ability to reorganize its energy investment in a relatively short period of time. Energy invested in growth might partially be used to recover from stress. In the present study, juvenile cobia in the $15 \%$ and $30 \%$ of microbial floc and microalgae Spirulina platensis treatments were observed to overcome stress due to osmotic pressure in a relatively short period of time (1 hour). So, the combination of microbial floc and microalgae Spirulina platensis diets can reduced of the negative impacts (stress) on juvenile cobia due to immersion. Similar results reported by Hastuti et al. (2004) by adding 1.5 ppm $\mathrm{Cr}^{+}{ }^{3}$ - feed yeast in giant gurami diet that was in turn subjected to thermal stress. Kuhn et al. (2009) stated that bacteria and other organisms contained in the microbial floc can function as probiotics. Lin et al. (2010) reported that the microalgae Spirulina platensis can have a positive impact on the fish health. Nakono et al. (2003) recorded that the lack of cellulose from the cellular structure of Spirulina render it easily digestible, thus, increase fish appetite, improve feed intake and nutrient digestibility and in turn enhance the health of fish, increasing the ability to fight off infections through the reduction of stress levels. The cortisol level increased along with the glucose level, for all treatment fish were reached its peak 2 hours after immersion.

On the other hand, an increase in both cortisol and glucose levels was observed in juvenile cobia fed on the $0 \%$ (control) and the $45 \%$ microbial floc and microalgae $\mathrm{Spi}$ rulina platensis diets an hour after immersion, indicating that the fish faced stress due to osmotic pressure. Similar results were reported by Trushenski et al. (2010) by air exposing 1 minute and low water for 0.5 hour of juvenile cobia. Costas et al. (2011) found similar results in the sole Senegalese fish (ex- 
posed to the air for 3 minutes) and Cnaani and Mclean (2009) for juvenile cobia with air exposure for 1 minute. All the experimental fish in our study returned to normal (homeostatis) six hours after fresh water immersion. Similar results were reported by Iwama $e t$ al. (2006) who found that in most fish, cortisol levels increase one hour after immersion and return to the initial level after 6 hours. Canani and Mclean (2009) and Trushenski et al. (2010) made similar observations in cobia fish.

\section{CONCLUSION}

The combination of microbial floc and microalgae Spirulina platensis (MFMS) at $15 \%$ produced the highest growth performance in juvenile cobia. The MFMS feed up to $30 \%$ can be used for juvenile cobia without negative effect on growth performance. The $15 \%$ and $30 \%$ of MFMS diets can reduced of the negative impacts (stress) on juvenile cobia due to immersion.

\section{REFERENCES}

Cnaani, A. and E. McLean. 2009. Timecourse response of cobia (Rachycentron canadum) to acute stress. Aquaculture, 289:140-142.

Costas, B., L.E.C. Conceicao, C. Aragao, J.A. Martos, I. Ruiz-Jarabo, J.M. Mancera, and A. Afonso. 2011. Physiological responses of Senegalese sole (Solea senegalensis Kaup, 18 58) after stress challenge: effects on non-spesific immune parameters, plasma free amino acids and energy metabolism. Aquaculture, 316:6876.

Crab, R. 2010. Bioflocs technology: an integrated system for the removal of nutrients and simultaneous production of feed in aquaculture. $\mathrm{PhD}$ thesis. Ghent University. 178p.

Crab, R., B. Chielens, M. Wille, P. Bossier, and W. Verstraete. 2010. The effect of different carbon sources on the nutritional value of bioflocs, a feed for Macrobrachium rosenbergii postlarvae. Aquaculture Research, 41: 559-567.

Crab, R., M. Kochva, W. Verstraete, and Y. Avnimelech. 2009. Bio-flocs technology application in over-wintering of tilapia. Aquaculture Engineering, 40: 105-112.

De Schryver, P., R. Crab, T. Defoirdt, N. Boon, and W. Verstraete. 2008. The basics of bioflocs technology: the added value for aquaculture. Aquaculture, 277:125-137.

Fujaya, Y. 2004. Fisiologi ikan. Dasar pengembangan teknik perikanan. Rineka Cipta, Jakarta. 179hlm.

Hastuti, S., I. Mokoginta, D. Darnas, and T. Sutardi. 2004. Stress resistensi terhadap stress dan respons imunitas ikan gurami (Osphronemus goura$m i$, Lac) yang diberi pakan mengandung kromium-ragi. J. Ilmu-ilmu Perairan dan Perikanan Indonesia, 11:15-21.

Iwama, G.K., L.O.B. Afonso, and M.M. Vijayan. 2006. Stress in fishes. In: Evans D.H. and J.B. Claiborne (eds.). The physiology of fishes. $\left(3^{\text {rd }}\right.$ Ed.). Taylor and Francis. USA. 319342pp.

Kaiser, J.B. and G.J. Holt. 2005. Species profile cobia. SRAC Publication No. 7202. 6p.

Kuhn, D.D., G.D. Boardman, A.L. Lawrence, L. Marsh and G.J. Flick, 2009. Microbial flocs generated in bioreactors is a superior replacement ingredient for fishmeal or soybean meal in shrimp feed. Aquaculture, 296:5157.

Liao, I.C., T.S. Huang, W.S. Tsai, C.M. Hsueh, S.L. Chang, and E.M. Leano. 2004. Cobia culture in Taiwan: current status and problems. Aquaculture, 237:155-165. 
Lin, Y.C., C.M. Tayag, C.L. Huang, W.C. Tsui, and J.C. Chen. 2010. White shrimp Litopenaeus vannamei that had received the hot-water extract of Spirulina platensis showed earlier recovery in immunity and upregulation of gene expressions after pH stress. Fish Shellfish Immunol., 29:1092-1098.

Macias-Sancho, J., L.H. Poersch, W. Bauer, L.A. Romano, W. Wasielesky and M.B. Tesser. 2014. Fishmeal substitution with Arthrospira (Spirulina platensis) in a practical diet for Litopenaeus vannamei: Effects on growth and immunological parameters. Aquaculture, 426:120-125

Mai, K.S., L. Zhang, Q.H. Ai, Q.Y. Duan, C.X. Zhang, H.T. Li, J.I. Wan, and Z.G. Liufu. 2006. Dietary lysine requirement of juvenile Japanese seabass, Lateolabrax japonicas. Aquaculture, 258:535-542.

Nakono, T. T. Yamaguchi, M. Sato and G.K. Iwama. 2003. Biological effects of carotenoids in fsh. International Seminar Effective Utilization of Marine Food Resource, Songkhla, Thailand. 1-15pp.

Olvera-Novoa, M.A., L.J. Domínguez-Cen, L. Olivera-Castillo, and C.A. Martínez-Palacios. 1998. Effect of the use of the microalga Spirulina maxi$m a$ as fish meal replacement in diets for tilapia, Oreochromis mossambicus (Peters), fry. Aquac. Res., 29:709715.

Schwarz, M.H., E. Mclean, and S.R. Craig. 2007. Research experience with cobia; larval rearing, juvenile nutriation and general physiology. In: Liau, L.C. and E.M. Leano (eds.). Cobia aquaculture: research, deve- lopment, and commercial production. Asian Fisheries Society; the fisheries society of Taiwan; World Aquaculture Society and National Taiwan Ocean University, Keelung. $1 \mathrm{p}$.

Silva-Neto, J., A.J.P. Nunes, H. Sahry-Neto, and M.V.C. Sal. 2012. Spirulina meal has acted as a strong feeding attractant for Litopenaeus vannamai at a very low dietary inclusion level. Aquac. Res., 43:430-437.

Teimouri, M., A.K. Amirkolae, and S. Yeganeh. 2013. The effects of Spirulina platensis meal as a feed supplement on growth performance and pigmentation of rainbow trout (Oncorhynchus mykiss). Aquaculture, 396:1419.

Trushenski, J., M. Schwarz, R. Takeuchi, B. Delbos, and L.A. Sampaio. 2010. Physiological responses of cobia Rachyecentron canadum following exposure to low water and air exposure stress challenges. Aquaculture, 307:173-177.

Tseng, Y.C. and H. Pung-Pung. 2008. Some insights into energy metabolism for osmoregulation in fish. Comp. Biochem. and Physiol., 148(C):419429.

Wedemeyer, G.A. 1996. Physiology of fish in intensive culture system. Chapman and Hall. New York. 227p.

Zhou, Q.C., J. Zhao, P. Li, H. Wang, and L. Wang. 2011. Evaluation of poultry by-product meal in commercial diets for juvenil cobia (Rachycentron canadum). Aquaculture, 322:122-127.

$\begin{array}{ll}\text { Diterima } & : 29 \text { Januari } 2016 \\ \text { Direview } & : 4 \text { Maret } 2016 \\ \text { Disetujui } & : 6 \text { April } 2016\end{array}$


